\title{
Pengaruh Fortifikasi Zat Besi Menggunakan Fe-Sulfat, Fe-Fumarat dan Na Fe EDTA Terhadap Kualitas Sensori Produk-Produk Olahan Tepung Terigu
}

\author{
The Effect of Iron Fortification using Fe-Sulfat, Fe-Fumarata \\ and Na Fe EDTA on Sensory Quality of Wheat Products
}

\author{
Dede R. Adawiyah ${ }^{1,2)^{*}}$, Tjahja Muhandri1 ${ }^{1,2)}$, Subarna ${ }^{1)}$, Sugiyono ${ }^{1)}$ \\ 1) Departemen Ilmu dan Teknologi Pangan, Fakultas Teknologi Pertanian, Institut Pertanian Bogor, Bogor \\ ${ }^{2)}$ Southeast Asian Food and Agricultural Science and Technology Center, LPPM, Institut Pertanian Bogor, Bogor
}

\begin{abstract}
The consumption of wheat flour in Indonesia is very high reaching 5.9 million tons during year 2016 and tends to increase steadily every year. The National Standardization Agency of Indonesia (BSN) of Wheat Flour (2009) requires the fortification with minimum iron of 50 ppm (as Fe-elemental). Study conducted byIndonesian ministry of health based on WHO recommendation (2006) states that for wheat consumption 75-149 g/day, fortificication wheat flour with iron should be as much as 60 ppm (in the form of Fe-fumarate or Fe-sulphate) or 40 ppm (in the form of NaFeEDTA compound), zinc 55 ppm (in the form of zinc oxide compound), and folic acid $2.6 \mathrm{ppm}$. The aim of this research was to evaluate the effect of fe fortification using 3 types of fe fortifcants: Ferous fumarat, Ferous sulfat and NaFeEDTA), zinc (in form of Zn oksida), vitamin B1, vitamin B2, asam folat (as premix) on sensory quality of wheat flour products such as bread, pao, cookies, noodle and macaroni. The result showed that Fe fortification using Fe-sulfat, $\mathrm{Fe}$-fumarat dan $\mathrm{Na} \mathrm{Fe}$-EDTA in wheat flour did not significantly affect sensory properties of breads and pao. For cookies, NaFeEDTA slightly affect on texture (slightly harder). For noodle and macaroni, NaFeEDTA dan ferous-sulfat affect on color of productss to become darker. Overall, fe-fumarat was recommended fortificant for iron fortification of wheat flour with the lowest effect on sensory properties of wheat products.
\end{abstract}

Keywords : Fe-fortification, Fe-fumarat, Fe-sulfat, NaFeEDTA

\begin{abstract}
Abstrak. Konsumsi tepung terigu di Indonesia sangat tinggi walaupun bukan sebagai makanan pokok yaitu mencapai 5.9 juta ton pada tahun 2016, dan cenderung mengalami peningktan sekitar 5\% dari tahun ke tahun. Badan Standardisasi Nasional Tepung Terigu (2009) telah mewajibkan fortifikasi tepung terigu dengan zat besi minimum $50 \mathrm{ppm}$ (bentuk senyawanya tidak ditentukan). Selama ini fortifikasi tepung terigu di Indonesia sudah dilakukan oleh produsen terigu menggunakan Fe-elemental (iron elemental). Akan tetapi berdasarkan kajian yang dilakukan oleh Kementrikan Kesehatan RI (Kemenkes) dan WHO, Fe-elemental memiliki kelemahan terutama dalam bioavailabilitas yang rendah. Oleh karena itu, pemerintah berencana menetapkan kebijakan penggunaan jenis fortifikan zat besi menggunakan fortifikan yang lebih baik dari sisi bioavailabilitasnya menggunakan Fe-sulfat, Fe-fumarat dan NaFeEDTA. Rekomendasi WHO menyatakan bahwa untuk konsumsi terigu 75-149 g/hari, fortifikasi tepung terigu dilakukan dengan penambahan zat besi sebanyak 60 ppm (dalam bentuk senyawa Fe-fumarat atau Fe-sulfat) atau 40 ppm (dalam bentuk senyawa NaFeEDTA), seng 55 ppm (dalam bentuk senyawa seng oksida), dan asam folat 2.6 ppm. Akan tetapi forfitifikasi zat besi biasanya berdampak pada perubahan sifat sensori dari produk. Oleh karena penelitian ini dilakukan bertujuan untuk mengevaluasi pengaruh fortifikasi zat besi (dalam bentuk senyawa Fe-fumarat, Fe-sulfat dan NaFeEDTA) terhadap kualitas sensori produk olahan terigu yaitu roti tawar, roti manis, cookies, mi basah, mi telur dan pasta macaroni.Pengujian dilakukan menggunakan uji beda dari kontrol (different from control test terhadap atribut kualitas sensori oleh 11 orang panelis terlatih. Hasil penelitian membuktikan bahwa penggunaan perbedaan jenis fortifikan Fe yaitu Fe-fumarat, Fe-sulfat dan Fe-EDTA tidak memberikan pengaruh yang siginifikan terhadapkkualitas sensori produk roti tawar, roti manis, dan pao. Untuk produk cookies, ditemui adanya sedikit perbedaan pada tekstur (agak sedikit lebih keras) terutama pada produk cookies dari terigu yang difortifikasi menggunakan NaFeEDTA. Untuk produk mi dan pasta, penggunaan terigu dengan fortifikan Fe-EDTA dan Fe-sulfat menyebabkan warna produk menjadi lebih gelap. Secara keseluruhan Fe-fumarat menunjukkan jenis fortifikan yang terbaik untuk fortifikasi tepung terigu dan tidak memberikan pengaruh yang terhadap sifat sensori produk olahanya.
\end{abstract}

Kata Kunci : Fe-fumarat, Fe-sulfat, fortifikasi Fe, NaFeEDTA 


Aplikasi Praktis: Hasil penelitian ini dapat dijadikan sebagai dasar dalam penetapan kebijakan oleh
pemerintah dan juga pertimbangan bagi produsen terigu terkait jenis fortifikan yang dapat digunakan untuk
keperluan fortifikasi zat besi pada tepung terigu di Indonesia oleh penentu kebijakan maupun oleh
produsen terigu.

\section{PENDAHULUAN}

Kekurangan zat besi adalah masalah gizi yang didapati di hampir seluruh Negara di dunia, yang menjadi penyebab anemia. WHO menyatakan bahwa terdapat lebih darilmilyar orang di dunia menderita anemia (Ottaway, 2008). Dibandingkan dengan strategi lain untuk memperbaiki kekungan zat besi anemia, fortifikasi zat besi pada makanan dilaporkan oleh banyak peneliti merupakan strategi yang paling efektif, paling murah untuk mempertahankan dan mencapai populasi yang lebih luas, serta menjamin pendekatan jangka panjang. Biaya untuk penanggulangan anemia gizi besi melalui program fortifikasi zat besi pada beras raskin, terigu, dan taburia serta suplementasi tablet besi sebesar Rp 1,95 triliun per tahun (Mangalik et al. 2016).

Konsumsi tepung terigu di Indonesia sangat tinggi walaupun bukan sebagai makanan pokok yaitu mencapai 5.9 juta ton pada tahun 2016, dan cenderung mengalami peningktan sekitar 5\% dari tahun ke tahun. Oleh karena itu, fortifikasi zat besi pada tepun terigu merupakan upaya yang strategis sebagai salah satu upaya untukmenurunkan masalah kekurangn zat gizi besi anemia di Indonesia. Badan Standardisasi Nasional Tepung Terigu (2009) mewajibkan fortifikasi tepung terigu dengan zat besi minimum 50 ppm (bentuk senyawanya tidak ditentukan), seng minimum $30 \mathrm{ppm}$, vitamin B1 (tiamin) minimum $2.5 \mathrm{ppm}$, vitamin B2 (riboflavin) minimum $4 \mathrm{ppm}$, dan asam folat minimum 2 ppm. Rekomendasi WHO (2009) menyatakan bahwa untuk konsumsi terigu 75-149 g/hari, fortifikasi tepung terigu dilakukan dengan penambahan zat besi sebanyak $60 \mathrm{ppm}$ (dalam bentuk senyawa Fefumarat atau Fe-sulfat) atau $40 \mathrm{ppm}$ (dalam bentuk senyawa NaFeEDTA), seng 55 ppm (dalam bentuk senyawa seng oksida), dan asam folat $2.6 \mathrm{ppm}$.

Kementrian Kesehatan RI mengusulkan perubahan (BSN 2009) tepung terigu dengan mengikuti rekomendasi WHO yaitu fortifikasi tepung terigu dengan zat besi minimum $60 \mathrm{ppm}$ (dalam bentuk senyawa Fe-fumarat atau $\mathrm{Fe}$-sulfat) atau $40 \mathrm{ppm}$ (dalam bentuk senyawa NaFeEDTA), seng minimum $55 \mathrm{ppm}$ (dalam bentuk senyawa seng oksida), vitamin B1 minimum $2.5 \mathrm{ppm}$, vitamin B2 minimum $4 \mathrm{ppm}$, dan asam folat minimum $2.6 \mathrm{ppm}$.

Ketersediaan zat besi sebagai fortifikan tergantung tidak hanya pada kelarutan fortifikan, tetapi juga pada komposisi makanan. Secara teknis, fortifikasi besi pada pada produk pangan memberikan tantangan tersendiri karena zat besi dengan bioavailabilitas terbaik cenderung berinteraksi kuat dengan komponen pangan yang selanjutnya menyebabkan perubahan sifat sensori yang tidak dikehendaki (Allen et al. 2006). Selama ini fortifikasi tepung terigu sudah dilakukan oleh produsen terigu menggunakan Fe-elemental (iron elemental). Akan tetapi berdasarkan kajian WHO (2006), penggunaan fortifikan Fe-elemental dinilai kurang efektif karena memiliki bioavailabilitas relatif yang rendah yaitu sekitar 75\% (Allen et al. 2006). Uauy et al. (2002) menyatakan bahwa Fe-elemental telah banyak digunakan untuk keperluan fortifikasi Fe pada banyak produk pangan, akan tetapi memiliki absorpsi yang rendah, sehingga menjadi tidak berguna sekalipun digunakan pada tingkat fortifikasi yang tinggi. Kementrian kesehatan RI melalui direktorat gizi masyarakat memutuskan untuk mengganti fortifikan zat besi pada terigu dengan fortifikan lain yang memiliki bioavailabilitas yang lebih tinggi yaitu $\mathrm{Fe}$ sulfat, Fe-fumarat atau NaFeEDTA. Akan tetapi sebelum kebijakan diterapkan perlu dilakukan konfirmasi apakah penggantian jenis fortifikan sebelumnya (Fe- elemental) dengan salah satu dari ketiga jenis fortifikan (Fe-sulfat, Fe-fumarat atau NaFeEDTA) mempengaruhi kualitas sensori produk olahannya. Oleh karena itu penelitian ini dilakukan untuk mengevaluasi pengaruh penggunaan 3 jenis fortifikan (Fe-sulfat, Fe-fumarat dan NaFeEDTA) pada tepung terigu dan efeknya terhadap kualitas sensori produk olahan terigu dibandingkan dengan terigu yang sebelumnya sudah beredar yang difortifikasi dengn Feelemental. Produk olahan terigu yang diujicobakan adalah roti tawar, roti manis, pao, cookies, mi basah, mi telur, pasta macaroni. Fortifikan yang digunakan dalam bentuk premix yang merupakan campuran dengan mikronutrien yang dipersyaratkan oleh Kemenkes seperti seng (dalam bentuk senyawa $\mathrm{Zn}$ oksida), vitamin B1, vitamin $\mathrm{B} 2$, dan asam folat.

\section{BAHAN DAN METODE}

\section{Bahan dan alat}

Bahan baku terigu yang digunakan berasal dari beberapa produsen terigu di Indonesia yang terdiri dari 2 jenis terigu yaitu terigu yang belum difortifikasi dan terigu yang sudah difortifikasi yang sesuai dengan Standar Nasional Indonesia yang sudah ada yaitu menggunakan (Fe-elemental).

Fortifikan yang digunakan adalah micronutrient premix yang mengandung 3 jenis Fe yaitu (1) Ferrous sulphate; (2) Ferrous fumarat; dan (3) Sodium iron EDTA. Ketiga fortifican $\mathrm{Fe}$ tersebut berasal dari Muhlenchemie $\mathrm{GmbH}$ \& Co. KG. Sesuai dengan spesifikasi produk, dosis fortifikan adalah 340 ppm untuk Fe-sulfat dan Fe-fumarat dan 500 ppm untuk NaFeEDTA. Komponen mikronutrien lain yang terkandung dalam premix yang digunkan selain zat besi adalah vitamin B1, vitamin B2, asam folat dan zinc. Spesifikasi ketiga Fe yang digunakan dapat dilihat pada Tabel 1. 
Bahan lain yang digunakan adalah bahan pembantu untuk membuat roti tawar, roti manis, cookies, mi dan pasta yaitu shortening, garam, gula, ragi, skim, bread improver, dan bahan pembantu lain untuk keperluan analisis sensori yang diperoleh dari toko komersial di daerah Bogor.

Tabel 1. Spesifikasi forfikatan yang digunakan Jenis Fortifikan Fe \& Dosis yang Disarankan

\begin{tabular}{lll}
\hline $\begin{array}{c}\text { Ferrous Fumarat } \\
\text { Dosis: } 340 \text { ppm }\end{array}$ & $\begin{array}{c}\text { Ferrous Sulphate } \\
\text { Dosis: } 340 \text { ppm }\end{array}$ & $\begin{array}{c}\text { Sodium Iron EDTA } \\
\text { Dosis: 500 ppm }\end{array}$ \\
\hline Vitamin B1:2.50 mg & Vitamin B1:2.50 mg & Vitamin B1:2.50 mg \\
Vitamin B2:4.00 mg & Vitamin B2:4.00 mg & Vitamin B2:4.00 mg \\
Folic acid:2.60 mg & Folic acid:2.60 mg & Folic acid:2.60 mg \\
Iron:60.00 mg & Iron:60.00 mg & Iron: $40.00 \mathrm{mg}$ \\
Zinc:55.00 & Zinc:55.00 & Zinc:55.00 \\
\hline
\end{tabular}

Peralatan yang digunakan adalah unit lini proses bakery dan mi/pasta di pilot plant Departemen Ilmu dan Teknologi Pangan dan SEAFAST Center IPB. Untuk pengujian sensori digunakan di laboratorium sensori Departemen Ilmu dan Teknologi Pangan, FATETASEAFAST Center, IPB.

\section{Metode pencampuran fortifikan}

Fortifikasi dilakukan untuk terigu dengan berat $5 \mathrm{~kg}$ terigu untuk keperluan aplikasi, dan pencampuran dilakukan dengan cara manual secara bertahap. Untuk FeSulfat dan Fe-Fumarat ditimbang 1.7 gr, sedangkan NaFeEDTA sebanyak 2.5 gr. Selanjutnya fortifikan dicampur dengan 100 gr terigu, diaduk sampai merata. Kemudian ditambah 200 gr terigu. Diaduk lagi menggunakan sampai merata. Setelah merata ditambahkan dengan 500 gr terigu, dan Diaduk menggunakan hand mixer selama 2 menit menggunakan kecepatan rendah, dilanjutkan dengan kecepatan tinggi selama 3 menit. Tahap akhir dicampur dengan sisa terigu dan diaduk menggunakan mixer besar selama 5 menit.

\section{Metode pembuatan roti tawar}

Roti tawar dibuat dengan formula standar yang biasa digunakan berbasis terigu (1000 g). Prosedur pembuatan roti tawar dilakukan dengan metode standar yang diawali dengan pencampuran.Semua bahan kering (1) (gula $60 \mathrm{~g}$, garam $12 \mathrm{~g}$, skim $20 \mathrm{~g}$ dan 3 gbread improver) dicampur dengan dikocok manual (menggunakan pengaduk plastik), dan bahan kering (2) yang terdiri dari Terigu (1000 g) dan ragi (15 g) dicampur secara terpisah. Bahan kering (1 dan 2) dicampur dengan mixer pada kecepatan rendah sambil diberi tambahan air es sebanyak $630 \mathrm{~mL}$ selama 2-3 menit. Setelah air tercampur, dimasukkan shortening (50 g), dan kecepatan mixer diubah menjadi kecepatan tinggi, serta proses pengadukan dilanjutkan selama 5-7 menit sampai kalis. Setelah kalis, adonan diistirahatkan dalam kondisi ditutup selama 10 menit. Sebanyak masing-masing $550 \mathrm{~g}$ adonan dipotong, dibulatkan, diistirahatkan selam 10 menit. Selanjutnya, adonan dipipihkan menggunakan molder, dan disusun dalam loyang bertutup untuk difermentasi selama 45-50 menit. Adonan yang sudah mengembang selanjutnya dipanggang dalam oven dengan pada suhu bagianatas $200^{\circ} \mathrm{C}$ dan suhu bagian bawah $230^{\circ} \mathrm{C}$, selama 30 menit. Roti tawar yang yang sudah dipanggang, dikeluarkan dari loyang dan didinginkan, serta dipotong-potong sebelum pengujian sensori dilaksanakan.

\section{Metode pembuatan roti manis}

Formula untuk roti manis terdiri dari $1000 \mathrm{~g}$ terigu, shortening dan margarin sebanyak masing-masing 60 dan $100 \mathrm{~g}$ garam dan gula sebanyak masing-masing $10 \mathrm{~g}$ dan $200 \mathrm{~g}, 25 \mathrm{~g}$ ragi, $40 \mathrm{~g}$ skim air dingin $450 \mathrm{~g}$, Improver Bakerine plus $4 \mathrm{~g}$, dan Telur sebanyak 2 butir. Prosedur pembuatan roti manis pada dasarnya sama dengan roti tawar, kecuali pada saat penimbangan adonan dimana adonan dipotong masing-masing $50 \mathrm{~g}$, dibulatkan, diistirahatkan selam 10 menit. Di roll dan dibentuk bulat. Setelah fermentasi selama 30 menit, adonan dipanggang dalam oven dengan suhu $180^{\circ} \mathrm{C}$, selama 10 menit. Roti yang sudah matang diangkat roti dari oven dan dibiarkan dingin sebelum pengujian dilakukan.

\section{Metode pembuatan pao}

Formula untuk pao terdiri dari g terigu 1000, shortening $100 \mathrm{~g}$, garam dan gula sebanyak masingmasing $10 \mathrm{~g}$ dan $160 \mathrm{~g}, 12 \mathrm{~g}$ ragi, $40 \mathrm{~g}$ skim, air dingin $500 \mathrm{~g}$, Improver $3 \mathrm{~g}$, dan baking powder $16 \mathrm{~g}$. Prosedur pembuatan pao dimulai dengan penimbangan semua bahan kering (gula, garam, skim, baking powder dan bread improver) dan dicampur dengan dikocok manual (menggunakan pengaduk plastic). Bahan kering lain (2) yang dicampur secara terpisah adalah terigu dengan ragi. Bahan-bahan kering tersebut (1 dan 2) dicampur dengan kecepatan rendah sambil ditambahkan air es selama 2-3 menit. Setelah air tercampur, dimasukkan shortening, dan kecepatan mixer diubah menjadi kecepatan tinggi. Pencampuran dilanjutkan selama 5-7 menit (sampai kalis), dan diistirahatkan dalam kondisi ditutup selama 10 menit. Adonan selanjutnya dipotong-potong seberat $50 \mathrm{~g}$, dibulatkan, dan diistirahatkan selama 10 menit. Kemudian adonan dipipihkan menggunakan roll kayu dan dibulatkan kembali sebelum dilakukan Fermentasi akhir selama 45 menit. Adonan yang telah difermentasi, selanjutnya dikukus selama 10 menit. Pao diangkat dari pengukus dan dibiarkan dingin sampai mencapai suhu kamar sebelum dilakukan pengujian karakter sensori.

\section{Metode pembuatan cookies}

Bahan baku untuk pembuatan cookies dilakukan menggunakan Formula untuk cookies standar yang terdiri dari terigu $250 \mathrm{~g}$, margarin $112 \mathrm{~g}$, garam $2.5 \mathrm{~g}$, gula 125 $\mathrm{g}$, baking powder $2.5 \mathrm{~g}$, skim $12.5 \mathrm{~g}$, air $17 \mathrm{~g}$, dan $2 \mathrm{~g}$ baking soda.

Prosedur pembuatan cookies dilakukan dengan mencampur semua bahan kering (gula, garam, skim, baking powder dan baking soda) dicampur dengan cara dikocok manual (menggunakan pengaduk plastik). Pembuatan krim dengan pencampuran margarin dan bahan kering menggunakan hand mixer. Setelah krim terbentuk, terigu dan air dimasukkan, dan diaduk menggunakan spatula dilanjutkan dengan pengadukan menggunakan hand mixer. Setelah adonan terbentuk, 
dipipihkan (di dalam lembaran plastik) dengan ketebalan sekitar $3 \mathrm{~mm}$. Tahap selanjutnya adalah pencetakan dan pemanggangan pada suhu $160^{\circ} \mathrm{C}$ selama 12 menit.

\section{Metode pembuatan mi}

Mi yang dibuat adalah jenis mi telur kering. Bahan baku untuk pembuatan mi terlur adalah terdiri dari Terigu $1000 \mathrm{~g}, 2$ butir telur, garam $20 \mathrm{~g}$, natrium bikarbonat $5 \mathrm{~g}$, dan air $225 \mathrm{~g}$. Prosedur pembuatan mi dimulai dengan mencampur garam, air dan telur diaduk hingga rata (campuran 1), dan Terigu dicampur dengan natrium bikarbonat (campuran 2) menggunakan hand mixer kecepatan rendah selama 2 menit. Campuran 1 dan campuran 2 dicampurkan dan diaduk terus selama 2 menit dengan kecepatan rendah, selanjutnya diubah menadi kecepatan tinggi dan pengadukan dilanjutkan selama 5 menit sampai kalis. Adonan dimasukkan dalam sheeter (roll) berulang-ulang sampai lembaran berukuran tebal $2 \mathrm{~mm}$ dan memiliki permukaan halus. Langkah selanjutnya adalah cutting atau pemotongan menjadi untaian mi, dan dikeringkan menggunakan tray drier pada suhu $60^{\circ} \mathrm{C}$ selama 3 jam.

\section{Metode pembuatan pasta (makaroni)}

Bahan baku untuk pembuatan pasta (makaroni) digunakan terdiri dari terigu $1000 \mathrm{~g}$, garam $20 \mathrm{~g}$, Natrium bikarbonat $5 \mathrm{~g}$, dan air $300 \mathrm{~g}$. Prosedur pembuatan macaroni dimulai dengan membuat mencampurkan dan natrium bikarbonat menggunakan hand mixer kecepatan rendah selama 2 menit. Selanjutnya ditambahkan larutan garam dan diaduk terus selama 2 menit dengan kecepatan rendah, dan diubah menadi kecepatan tinggi dan pengadukan dilanjutkan selama 5 menit sampai adonan menjadi kalis. Selanjutya adonan dimasukkan dalam ekstruder pasta yang dilengkapi dengan pemotong. Potongan pasta makaroni kemudian dikeringkan menggunakan tray drier pada suhu $60^{\circ} \mathrm{C}$ selama 3 jam.

\section{Metode pengujian sensori}

Panelis yang digunakan untuk pengujian adalah 11 orang panelis terlatih internal Departemen ITP, FATETA, IPB yang sudah melalui proses seleksi dan training serta memiliki pengalaman dalam melakukan pengujian berbagai produk pangan lebih dari 1 tahun. Semua panelis mendapatkan penjelasan terlebih dahulu mengenai teknis pengujian dan pengenalan terhadap sampel kontrol.

Metode uji sensori yang digunakan adalah different from control test yang mengacu pada Meilgaard et al. (2016) dimana sebagai kontrol adalah produk yang dibuat dari terigu yang difortifikasi sesuai Standar Nasional Indonesia yaitu $\mathrm{Fe}$-elemental. Metode penyajian sampel dilakukan dua arah dengan membandingkan antara sampel dengan kontrol (R). Pada setiap pengujian terdapat satu sampel sebagai blind control yaitu sampel kontrol (R) yang dijadikan sampel uji. Semua sampel uji diberi kode 3 digit angka acak. Penyajian sampel dilakukan secara monadik atau satu per satu. Dalam satu kali penyajian disajikan dua sampel yang terdiri dari sampel kontrol (R) dan sampel uji.
Kriteria pengujian untuk roti tawar, roti manis dan pao terdiri dari (1) warna crumb (sama (0) atau lebih terang $(+1-+3)$ / lebih gelap $(-1-3)$ dari kontrol); (2) pori-pori (sama atau lebih besar $(+1-+3)$ lebih kecil $(-1$ -3) dari kontrol); (3) aroma roti (sama dengan kontrol atau berbeda/menyimpang dari intensitas sangat lemah sangat besar(+1- +3)); (4) tekstur (sama (0) atau lebih kering (-1 - -3)/lebih lembut $(+1-+3)$ dari kontrol); (5) rasa (sama dengan kontrol atau berbeda/menyimpang. Jika terdapat penyimpangan diminta untuk mendeskripsikan); dan (7) perbedaan secara/keseluruhan/overall (sama (0) atau berbeda dari kontrol (1-7)).

Kriteria pengujian untuk produk cookies terdiri dari: (1) warna (sama atau lebih terang/lebih gelap dari kontrol); (2) aroma roti (sama dengan kontrol atau berbeda/menyimpang. Jika terdapat penyimpangan diminta untuk mendeskripsikan); (3) tekstur (sama atau lebih keras/lebih lunak dari kontrol); (4) rasa (sama dengan kontrol atau berbeda/menyimpang. Jika terdapat penyimpangan diminta untuk mendeskripsikan); (7) overall/keseluruhan ( $\mathrm{sama}=0$ atau berbeda (dari sangat kecil (1) - sangat besar (7) perbedaannya) dari kontrol).

Pengujian mi telur dilakukan terhadap mi telur yang sudah direhidrasi dengan cara merebus mi dalam air mendidih selama 4 menit, selanjutnya ditiriskan dan dimasukkan ke dalam air dingin, serta ditiriskan kembali sebelum pengujian. Kriteria pengujian untuk produk mi terdiri dari (1) warna (sama atau lebih terang (+1+3 )/lebih gelap (-1 - -3) dari kontrol); (2) aroma roti (sama dengan kontrol atau berbeda/menyimpang. Jika terdapat penyimpangan diminta untuk mendeskripsikan); (3) elastisitas dengan cara untaian dipegang sepanjang 15 $\mathrm{cm}$ dan ditarik perlahan (sama atau lebih elastis $(+1-$ +3 )/lebih tidak elastis (-1 - -3) dari kontrol); (4) tekstur dengan cara penggigitan atau pengunyahan (sama atau lebih kerasn (+1- +3) /lebih lunak (-1 - -3) dari kontrol); (5) rasa (sama dengan kontrol atau berbeda/menyimpang. Jika terdapat penyimpangan diminta untuk mendeskripsikan); (6) overall/keseluruhan ( kecil (1) - sangat besar (7) perbedaannya) dari kontrol

Untuk pasta, dipersiapkan sama halnya dengan persiapan untuk mi telur yaitu dengan cara merebus pasta kering dalam air mendidih selama 5.5 menit, selanjutnya ditiriskan dan dimasukkan ke dalam air dingin, serta ditiriskan kembali sebelum pengujian Kriteria pengujian untuk produk pasta terdiri dari (1) warna (sama atau lebih terang $(+1-+3)$ / lebih gelap (-1 - -3) dari kontrol); (2) Aroma roti sama $=0$ atau berbeda (dari kecil (1) - sangat besar (7) perbedaannya) dari kontrol Jika terdapat penyimpangan/perbedaan diminta untuk mendeskripsikan); (3) tekstur (sama atau lebih keras $(+1-+3)$ /lebih lunak (-1 - -3) dari kontrol); (4) rasa sama $=0$ atau berbeda (dari kecil (1) - sangat besar (7) perbedaannya) dari kontrol. Jika terdapat penyimpangan/perbedaan diminta untuk mendeskripsikan); (5) overall/keseluruhan (sama = 0 atau berbeda (dari kecil (1) - sangat besar (7) perbedaannya) dari kontrol. 


\section{Pengolahan data}

Data yang diperoleh dioleh secara statistik menggunakan analisis univariant two way (without interaction) dengan rancangan desain kelompok (panelis sebagai kelompok) menggunakan program SPSS versi 22 dengan dengan tingkat signifikansi 5\% $(\mathrm{p}=0.05)$. Selanjutnya jika ditemui adanya perbedaan antar sampel (p sampel < 0.05), dilakukan uji lanjut dengan dunnet untuk melihat perbedaan antara $\mathrm{R}$ (kontrol) dengan ketiga sampel dengan fortifikan Fe-fumarat, Fe-sulfat dan Fe-EDTA yang dinyatakan sebagai mean difference.

\section{HASIL DAN PEMBAHASAN}

\section{Roti tawar}

Hasil analisis data pada Tabel 1 menunjukkan bahwa roti tawar yang dibuat dari terigu dengan jenis fortifikan Fe-fumarat, Fe-sulfat dan Fe-EDTA dibandingkan dengan roti tawar kontrol yang dibuat dari terigu yang difortifikasi sesuai Standar Nasional Indonesia saat ini (Fe-elemental) tidak menunjukkan perbedaan yang signifikan terhadap semua karakter sensori yang dievaluasi (warna crumb, pori-pori, aroma, tekstur, rasa), kecuali pada warna crust. Perbedaan warna crust yang teramati lebih disebabkan karena proses pemanggangan yang tidak terlalu seragam, bukan disebabkan oleh adanya perbedaan jenis fortifikan $\mathrm{Fe}$ yang digunakan. Hasil yang serupa teramati pada kedua terigu yang berasal dari produsen yang berbeda.

\section{Roti manis}

Pada Tabel 2 memperlihatkan hasil analisis different from control test pada produk roti manis. Warna crust tidak dilakukan pengujian mengingat warna produk roti manis yang dihasilkan memiliki variasi warna coklat akibat perbedaan posisi didalam oven, sehingga pengujian difokuskan pada crumb dan penentuan keputusan perbedaan secara overall tidak mengikut sertakan warna crumb.

Tabel 2. Rekapitulasi nilai signifikansi dari hasil anova pada $\alpha 5 \%$ parameter sensori roti tawar yang dibuat dari terigu dengan yang difortifikasi dengan $\mathrm{Fe}$ elemental (kontrol), Fe-fumarat, Fe-sulfat dan $\mathrm{NaFeEDTA}$

Nilai Signifikan Level Pengujian dengan Sumber Terigu

\begin{tabular}{lcc}
\multicolumn{3}{c}{ Nilai Signifikan Level Pengujian dengan Sumber Terigu } \\
\hline Warna crust & Terigu 1 & Terigu 2 \\
Warna crumb & $0.000^{*}$ & 0.000 \\
Pori-pori & 0.901 & 0.138 \\
Aroma & 0.185 & 0.070 \\
Tekstur & 0.986 & 0.973 \\
Rasa & 0.276 & 0.360 \\
Perbedaan Overall & 0.307 & 0.592 \\
\hline
\end{tabular}

Keterangan: *berbeda signifikan pada $\alpha=5 \%(\mathrm{p}=0.05)$

Dari Tabel 2 dapat dilihat bahwa pada terigu 1 tidak ditemui adanya perbedaan yang signifikan antara sampel kontrol dengan sampel lain yang dibuat dari terigu dengan fortifikan yang berbeda. Akan tetapi pada terigu 2 , panelis merasakan adanya perbedaan pada aroma dan rasa.
Hasil uji lanjut menggunakan uji dunnet menunjukkan bahwa perbedaan yang signifikan terjadi pada sampel dengan fortifikan Fe-EDTA. Nilai perbedaan rata-rata (mean difference) antara roti manis kontrol dan Fe-EDTA adalah sebesar 1.1 untuk aroma dan 0.7 untuk rasa. Mengacu pada kuesioner yang diberikan kepada panelis, pengujian dilakukan rasa dan aroma yang digunakan adalah mengidentifikasi apakah sampel sama dengan kontrol (skala $=0$ ) atau ada penyimpangan dengan rentang (1=sangat lemah $-7=$ sangat besar). Dengan demikian penyimpangan rasa dan aroma yang dideteksi oleh panelis berada pada intensitas sangat lemah. Gambar 1 menunjukkan tingkatan perbedaan nilai rata-rata (mean difference) setiap parameter roti manis antara produk dengan masing-masing fortifikan (Fe-sulfat, fumarat dan sodium EDTA) dengan produk standar yang dibuat dengan terigu yang difortifikasi dengan Fe-elemental. Perbedaan yang terlihat lebih besar adalah roti manis yang dengan fortifikan NaFeEDTA pada karakter warna crumb, pori dan rasa. Roti manis dengan perlakuan Fefumarat menunjukkan tingkat perbedaan yang paling kecil, sedangkan pada perlakuan Fe-sulfat terlihat perbedaan kecil terjadi pada karakter tekstur. Akan tetapi tingkat perbedaan tersebut masih berada pada kisaran sangat kecil atau sangat lemah (kurang dari 1). pengujian sensori dengan uji different from control terutama untuk rasa,aroma dan overall dilakukan dengan mengidentifikasi apakah sampel sama dengan kontrol $($ skala $=0)$ atau ada penyimpangan dengan rentang ( $1=$ sangat lemah $7=$ sangat besar).

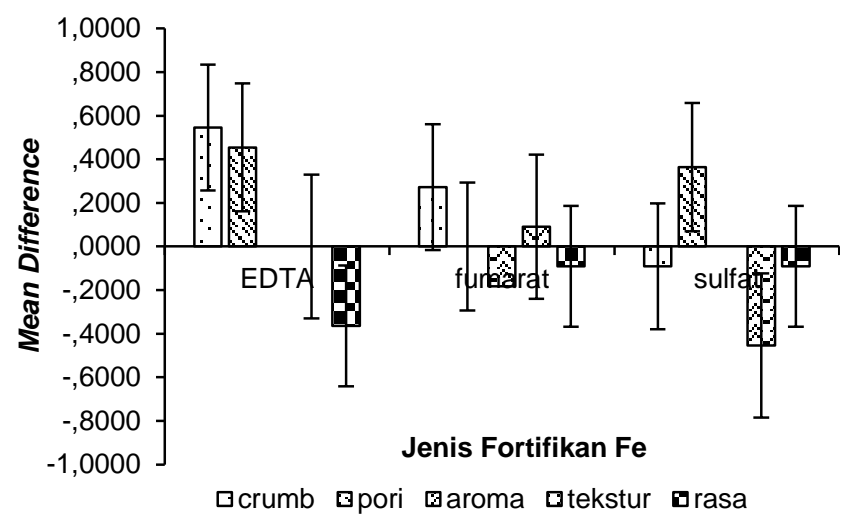

Gambar 1. Tingkat perbedaan rata-rata (mean difference) parameter roti manis yang difortifikasi dengan NaFeEDTA, Fe-fumarat dan Fe-sulfat terhadap kontrol ( Fe-elemental)

Dari data yang diperoleh diatas, dapat disimpulkan bahwa penggunaan ketiga fortifikan zat besi dalam bentuk Fe-fumarat, Fe-sulfat, Fe-EDTA tidak memberikan pengaruh yang signifikan terhadap sifat sensori produk roti manis secara keseluruhan pada tingkat signifikansi 5\% dibandingkan dengan roti manis kontrol yang menggunakan terigu dengan fortifikan $\mathrm{Fe}$ elemental. Penyimpangan yang ditemui pada rasa dan aroma dideteksi pada tingkatan sangat lemah, dan tidak terlalu berpengaruh pada sifat sensori secara keseluruhan menggunakan uji beda dari kontrol (different from control test). 


\section{Pao}

Hasil analisis kualitas sensori produk pao menunjukkan bahwa penggunaan fortifikan Fe yang berbeda memberikan pengaruh yang signifikan terhadap warna crumb terutama pada terigu 1 dan pori-pori pao baik untuk terigu 1 maupun 2 (Tabel 3). Pengujian data lebih lanjut terhadap warna pao dari tepung terigu menunjukkan bahwa perbedaan dideteksi pada sampel pao dengan fortifikan NaFeEDTA yang dinilai pada tingkat sangat sedikit lebih gelap (mean difference $=0.7)($ Gambar 2$)$. Demikian juga halnya pada perbedaan yang dideteksi pada karakter pori-pori pao. Perbedaan karakter pori-pori yang juga diperoleh dari hasil analisis statistik (Tabel 3), dimana perbedaan terjadi antara kontrol dengan terigu dengan Fe-EDTA yang dinilai memiliki pori-pori sedikit lebih kecil dari pao kontrol (mean difference $=-1.25$ ). Akan tetapi besarnya pori-pori pao lebih banyak dipengaruhi oleh proses pengolahan baik pada saat fermentasi dan pengukusan.

Tabel 3. Rekapitulasi nilai signifikansi dari hasil anova pada $\alpha 5 \%$ parameter sensori roti manis Rekapitulasi nilai signifikansi dari hasil anova pada $\alpha 5 \%$ parameter sensori roti tawar yang dibuat dari terigu dengan yang difortifikasi dengan Fe-elemental (kontrol), Fefumarat, Fe-sulfat dan NaFeEDTA

\begin{tabular}{|c|c|c|}
\hline \multicolumn{3}{|c|}{ Nilai Signifikan Level Pengujian dengan Sumber Terigu } \\
\hline Parameter Sensori & Ulangan 1 & Ulangan 2 \\
\hline Warna crumb & 0.407 & 0.474 \\
\hline Pori-pori & 0.123 & 0.408 \\
\hline Aroma & 0.738 & $0.045^{*}$ \\
\hline Tekstur & 0.081 & 0.598 \\
\hline Rasa & 0.733 & $0.010^{*}$ \\
\hline Perbedaan Overall & 0.388 & 0.206 \\
\hline
\end{tabular}

Keterangan: *berbeda signifikan pada $\alpha=5 \%(\mathrm{p}=0.05)$

Walaupun ditemui adanya sedikit perbedaan pada warna dan pori-pori, akan tetapi secara keseluruhan perbedaan tersebut tidak berbeda dengan kontrol baik pada kedua terigu yang digunakan $(\mathrm{p}>0.05)$. Hal tersebut karena perbedaan pada warna maupun pori-pori pao sangat kecil dibandingkan dengan kontrol (mean difference $=0.6-1.2$ ). Dengan kata lain, secara keseluruhan tidak ditemui adanya perbedaan sifat sensori secara keseluruhan pada produk pao yang dibuat dengan terigu dengan fortifikan Fe-sulfat, Fe-fumarat, dan FeEDTA dibandingkan dengan pao yang dibuat dengan terigu kontrol yang mengandung Fe-elemental.

\section{Cookies}

Analisis sifat sensori cookies menunjukkan bahwa perbedaan fortifikan menyebabkan perbedaan yang signifikan terhadap tekstur, rasa dan sifat sensori secara keseluruhan pada cookies yang menggunakan terigu 1 . Sedangkan jika menggunakan terigu 2 perbedaan hanya ditemui pada tekstur (Tabel 4).

Berdasarkan pada uji lanjut dunnet yang ditampilkan pada Gambar 3, perbedaan terjadi terutama pada cookies yang difortifikasi menggunakan Fe-EDTA. Tekstur cookies menggunakan terigu yang difortifikasi menggunakan Fe-EDTA sedikit lebih keras (mean difference sekitar 1 atau sangat sedikit lebih keras) dibandingkan dengan kontrol (Fe-elemental). Perbedaan juga terdeteksi pada karakter rasa, walaupun panelis belum mampu mengidentifikasi dan mendeskripsikan jenis perbedaan atau penyimpangan yang terjadi pada cookies yang difortifikasi dengan Fe-EDTA.

Tabel 4. Rekapitulasi nilai signifikansi perbedaan pao yang dibuat dari terigu dengan yang difortifikasi dengan Fe-elemental (kontrol), Fe-fumarat, Fe-sulfat dan $\mathrm{NaFeEDTA}$

\begin{tabular}{|c|c|c|}
\hline \multicolumn{3}{|c|}{ Nilai Signifikan Level Pengujian dengan Sumber Terigu } \\
\hline Parameter Sensori & Ulangan 1 & Ulangan 2 \\
\hline Warna crumb & $0.046^{\star}$ & 0.277 \\
\hline Pori-pori & $0.002^{*}$ & $0.020^{*}$ \\
\hline Aroma & 0.076 & 0.694 \\
\hline Tekstur & 0.876 & 0.422 \\
\hline Rasa & 0.141 & 0.361 \\
\hline Perbedaan Overall & 0.054 & 0.772 \\
\hline
\end{tabular}

Keterangan: *berbeda signifikan pada $\alpha=5 \%(\mathrm{p}=0.05)$

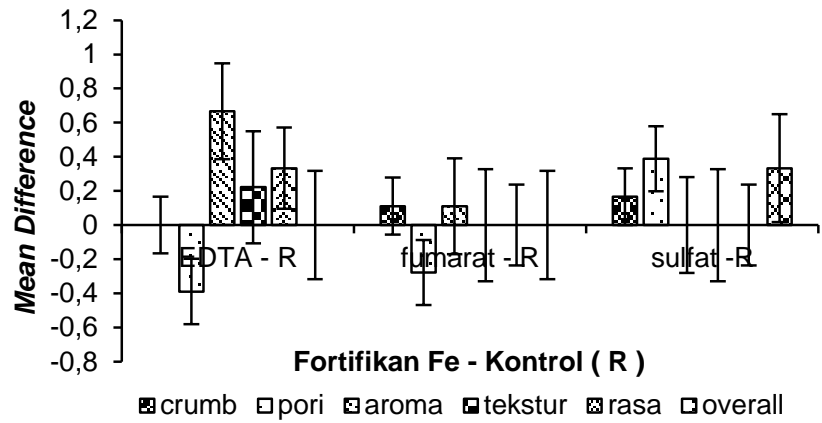

Gambar 2. Tingkat perbedaan rata-rata (mean difference) parameter roti kukus (pao) yang difortifikasi dengan NaFeEDTA, Fe-fumarat dan Fe-sulfat terhadap kontrol ( Fe-elemental)

Adanya perbedaan pada kedua atribut tersebut berdampak pada perbedaan secara keseluruhan dimana cookies menggunakan terigu 1 dengan fortifikan $\mathrm{Fe}-$ EDTA berbeda dari kontrol dengan tingkat perbedaan yang sangat kecil (mean difference $=1.1$ ). Sedangkan pada cookies yang dibuat dari terigu 2 dengan 3 fortifikan (Fe-sulfat, Fe-fumarat, Fe-EDTA). Hal tersebut terjadi karena penambahan fortifikan Na-Fe EDTA pada terigu lebih tinggi $(500 \mathrm{ppm})$ dibandingkan Fe-sulfat dan Fefumarat yang masing-masing ditambahkan sebanyak 340 ppm. Kandungan besi pada Na-Fe EDTA adalah 13\% sedangkan pada $\mathrm{Fe}$-sulfat $20 \%$, dan pada $\mathrm{Fe}$-fumarat adalah 33\% (Allen et al. 2006). Oleh karena selanjutnya pada produk cookies yang dihasilkan jumlah total mineral menjadi lebih tinggi dari yang lainnya, dan selanjutnya berdampak pada perubahan tekstur. Aulia et al. (2017) melaporkan fortifikasi menggunakan NaFeEDTA pada cookies ubi jalar kuning sebagai produk alternatif untuk menanggulangi anemia defisiensi besi, dan menyatakan bahwa Hasil uji sensori menggunakan metode uji penerimaan (hedonik) cookies dengan yang difortfikasi $\mathrm{NaFeEDTA}$ memiliki penerimaan warna, aroma dan tekstur, cookies yang lebih disukai dibanding cookies kontrol (tanpa fortifikasi).

$\mathrm{Na}$ Fe-EDTA sebenarnya adalah jenis fortifikan yang baik dengan bioavailabilitas yang tinggi yaitu 2-3 kali lebih besar dari Fe-sulfat dan Fe-fumarat karena dapat 
melindungi dari f inhibitor seperti fitat dan polifenol (Allen et al. 2006; Andrian et al. 2015). Husna (2011) menggunakan Fe-sulfat untuk fortfikasi zat besi pada susu kedele dan tempe yang dikombinasikan dengan Na2EDTA untuk mencegah pengikatan zat besi oleh fitat yang banyak ditemui pada kacang-kacangan. Akan tetapi kelemahan dari fortifikan ini adalah karena kandungan Fe yang lebih kecil dan harganya yang lebih mahal dibandingkan dengan Fe-sulfat dan Fe-fumarat (Allen et al. 2006).

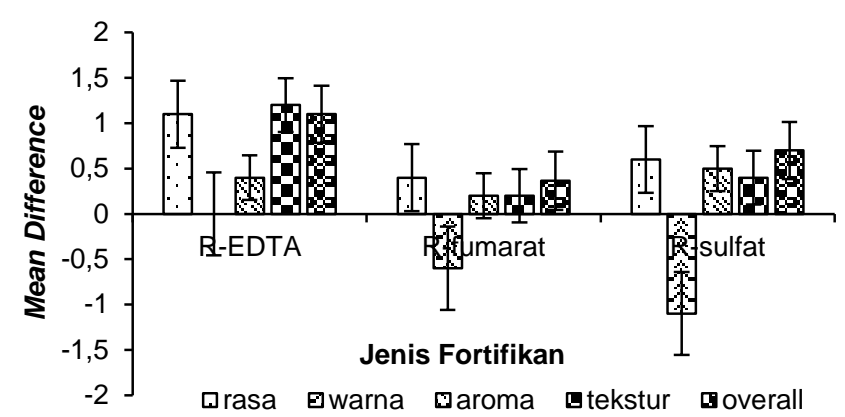

Gambar 3. Tingkat perbedaan rata-rata (mean difference) parameter produk cookies yang difortifikasi dengan NaFeEDTA, Fe-fumarat dan Fe-sulfat terhadap kontrol (Fe-elemental)

Mi

Hasil analisis statistik data pengujian produk mi menunjukkan bahwa perbedaan jenis fortifikan $\mathrm{Fe}$ berdampak signifikan pada warna dan aroma produk mi yang dibuat baik dengan terigu 1 dan terigu 2 (Tabel 6). Berdasarkan Gambar 4 tersebut dapat dilihat bahwa perubahan yang terlihat paling doniman adalah pada mi yang menggunakan terigu dengan fortifikan Fe-sulfat baik pada hampir semua karakter sensori mi (warna, aroma, tekstur, dan overall). Fenomema yang sama ditunjukkan pada pasta dimana hasil analisis data sensori pengujian pasta kering yang direhidrasi menunjukkan bahwa perbedaan fortifikan Fe menghasilkan perbedaan warna yang sangat signifikan $(\mathrm{p}=0.000)$ dan selanjutnya menyebabkan pasta memiliki perbedaan sensori secara keseluruhan (Tabel 7).

Tabel 5.Rekapitulasi nilai signifikansi perbedaan cookies yang dibuat dari terigu dengan yang difortifikasi dengan Fe-elemental (kontrol), Fe-fumarat, Fesulfat dan NaFeEDTA

\begin{tabular}{lcc}
\hline \multicolumn{2}{c}{ Nilai Signifikan Level Pengujian dengan Sumber Terigu } \\
\hline Parameter Sensori & Ulangan 1 & Ulangan 2 \\
\hline Warna & 0.066 & 0.214 \\
Aroma & 0.212 & 0.803 \\
Tekstur & $0.002^{*}$ & $0.006^{\star}$ \\
Rasa & $0.045^{*}$ & 0.703 \\
Perbedaan Overall & $0.014^{*}$ & 0.353 \\
\hline
\end{tabular}

Keterangan: *berbeda signifikan pada $\alpha=5 \%(\mathrm{p}=0.05)$

Hasil uji lanjut dunnet mem-perlihatkan bahwa perbedaan ditemui pada pasta dengan fortifikan Fe-EDTA dan Fe-sulfat). Perbedaan warna dengan intensitas yang lebih gelap (mean difference $=1.7$ ) adalah pada pasta dengan fortifikan Fe-sulfat dibandingkan dengan kontrol, diikuti dengan fortifikan NaFeEDTA dan perbedaan paling kecil adalah pada pasta dengan fortifikan Fefumarat (Gambar 5).

Tabel 6. Nilai signifikansi perbedaan mi yang dibuat dari terigu dengan yang difortifikasi dengan $\mathrm{Fe}$ elemental (kontrol), Fe-fumarat, Fe-sulfat dan NaFeEDTA

\begin{tabular}{|c|c|c|}
\hline \multicolumn{3}{|c|}{ Nilai Signifikan Level Pengujian dengan Sumber Terigu } \\
\hline Parameter Sensori & Ulangan 1 & Ulangan 2 \\
\hline Warna & $0.002^{*}$ & $0.000^{*}$ \\
\hline Aroma & $0.034^{*}$ & $0.007^{*}$ \\
\hline elastisitas & 0.252 & 0.071 \\
\hline Tekstur & 0.438 & 0.153 \\
\hline Rasa & 0.406 & 0.157 \\
\hline Perbedaan Overall & 0.833 & 0.087 \\
\hline
\end{tabular}

Keterangan: *berbeda signifikan pada $\alpha=5 \%(\mathrm{p}=0.05)$

Tabel 7. Rekapitulasi nilai signifikansi perbedaan pasta yang dibuat dari terigu dengan yang difortifikasi dengan Fe-elemental (kontrol), Fe-fumarat, Fe-sulfat dan NaFeEDTA

\begin{tabular}{lc}
\hline \multicolumn{1}{c}{ Parameter Sensori } & Signifikan Level \\
\hline Warna & $0.000^{*}$ \\
Aroma & 0.594 \\
Tekstur & 0.259 \\
Rasa & 0.406 \\
Perbedaan Overall & $0.007^{*}$ \\
\hline
\end{tabular}

Keterangan: *berbeda signifikan pada $\alpha=5 \%(\mathrm{p}=0.05)$

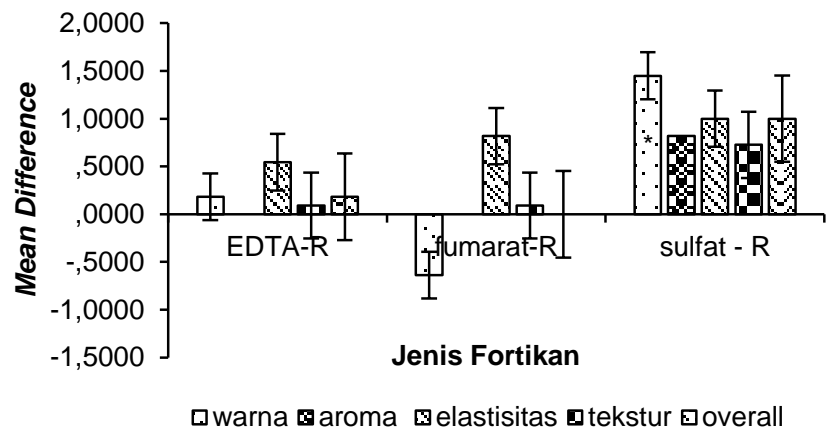

Gambar 4. Tingkat perbedaan rata-rata (mean difference) parameter produk mi basah yang difortifikasi dengan NaFeEDTA, Fe-fumarat dan Fe-sulfat terhadap kontrol (Fe-elemental)

Allen et al. (2006) menyatakan bahwa Fe-sulfat termasuk jenis fortifikan besi yang sedikit larut dalam air, tetapi larut dalam asam. Fortifikan yang masuk dalam katagori tersebut terabsorp dengan sangat baik dalam makanan sehingga besar kemungkinan menyebabkan perubahan sifat organoleptik pada saat diaplikasikan ke produk pangan. Petunjuk fortifikasi mikronutrien pada pangan menurut WHO (2006) mengklasifikasikan fortifikan $\mathrm{Fe}$ untuk keperluan fortifikasi uk pangan menjadi tiga katagori yaitu (1) larut air (2) sedikit larut air dan larut dalam asam lemah (3) tidak larut air, dan sedikit larut dalam asam. Fe-sulfat termasuk dalam katagori fortifikan Fe yang larut air. Kelemahan dari tipe fortifikan yang larut air adalah dampak yang tidak diinginkan terhadap kualitas sensori atau organoleptik produk pangan yang difortifikasi seperti yang dibuktikan pada penelitian ini karena mampu bereaksi dengan komponen produk pangan dan menghasilkan mi dan pasta dengan warna yang lebih gelap pada saat direhidrasi. Warna mi yang dihasilkan dari kedua fortifikan tersebut sedikit 
lebih gelap (mean difference $=0.63-0.72$ ). Sedangkan pada pasta dengan fortifikan Fe-EDTA, warna pasta dari Fe-EDTA dinilai dengan intensitas sedikit lebih gelap ( mean difference $=1.1$ ).

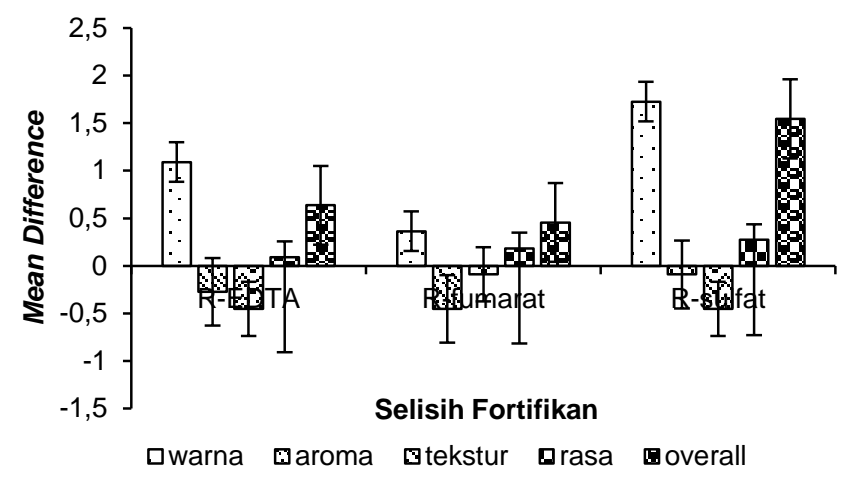

Gambar 5. Tingkat perbedaan rata-rata (mean difference) parameter produk pasta basah yang difortifikasi dengan NaFeEDTA, Fefumarat dan Fe-sulfat terhadap kontrol (R/ Fe-elemental)

Perbedaan aroma teridentifikasi ditemui pada mi dengan fortifikan Fe-sulfat baik pada mi telur yang sudah direhidrasi. Mi telur dengan fortifikan Fe-sulfat memiliki aroma amis telur yang lebih kut dibandingkan dengan mi kontrol (dengan fortifikan Fe-elemental). Mempertimbangkan nilai mean-difference yang dihasilkan pada mi dari kedua terigu (berkisar pada $(0.8-1.5)$ menunjukkan bahwa ada peningkatkan intensitas aroma telur sedikit lebih kuat dibandingkan dengan mi kontrol. Menurut Lotfi et al. (1996), reaksi oksidasi lemak dan diskolorasi atau perubahan warna merupakan masalah utama dalam penggunaan Ferrous sulfat. Oleh karena itu direkomendasikan menggunakannya dalam bentuk yang terenkapsulasi. Sejauh ini ferrous sulfat banyak digunakan sebagai fortifikan baik untuk susu cair maupun bubuk terutama di US dan Canada, serta cukup memuaskan digunakan dalam formula untuk bayi dan produk pangan lain (Allen et al. 2006). Untuk keperluan pasar yang lebih besar, disarankan menggunakan Ferrous sulphate (Fe-sulfat) terenkapsulasi untuk menghilangkan atau mengurangi resiko perubahan warna pada produk (Chaudari dan Fanion 2008). Hurrell et al. (2010), merekomendasikan menggunakan penambahan $20 \mathrm{ppm}$ besi sebagai $\mathrm{NaFeEDTA}$, atau $30 \mathrm{ppm}$ sebagai ferrous sulfate or ferrous fumarate kering jika konsumsi tepung terigu per hari rendah $(<$ atau $=0.8 \%$ kadar abu), sedangkan jika konsumsi tepung terigu tinggi (>0.8\% kadar abu), NaFeEDTA adalah satu-satunya senyawa $\mathrm{Fe}$ yang direkomendasikan.

Perbedaan intensitas warna yang sedikit lebih gelap dan aroma telur yang sedikit lebih kuat dibandingkan kontrol tidak berdampak pada penilaian secara keseluruhan dari produk mi. Dari Tabel 15 dapat dilihat pada tidak ada perbedaan sifat sensori secara keseluruhan antara mi dengan fortifikan Fe-EDTA, Fe-fumarat, dan Fe-sulfat dengan mi kontrol dengan fortifikan Fe-elemental sesuai Standar Nasional Indonesia.

Kriteria umum pemilihan fortifikan menurut Lofti (1998) salah satunya adalah: (2) tidak ada interaksi dengan sistem flavor dan warna; (3) biaya ekonomis dan terjangkau; (4) warna, kelarutan dan ukuran partikel yang dapat diterima; (5) tersedia secara komersial dengan kualitas food grade; (6) tersedia dalam bentuk terenkapsulasi jika dibutuhkan; (7) kelayakan ditambahkan dan didispersikan selama penampuran kering atau spray coating menggunakan premix jika diperlukan. Untuk keperluan pasar yang lebih besar, disarankan menggunakan Ferrous sulphate (Fe-sulfat) terenkapsulasi untuk menghilangkan atau mengurangi resiko perubahan warna pada produk (Chaudari dan Fanion 2008).

\section{KESIMPULAN}

Penggunaan perbedaan jenis fortifikan $\mathrm{Fe}$ yaitu $\mathrm{Fe}-$ fumarat, Fe-sulfat dan Fe-EDTA tidak memberikan pengaruh yang siginifikan terhadap produk roti tawar, roti manis, dan pao. Pada roti manis dengan fortifikan $\mathrm{Fe}-$ EDTA ditemui perbedaan dengan kontrol pada karakter rasa dan aroma akan tetapi pada intensitas perbedaan penyimpangan rasa dan aroma yang sangat kecil. Untuk produk cookies, ditemui adanya sedikit perbedaan pada tekstur (agak sedikit lebih keras) teruatpa pada produk cookies dari terigu dengan fortifikan Fe-EDTA. Untuk produk mi dan pasta, penggunaan terigu dengan fortifikan Fe-EDTA dan Fe-sulfat menyebabkan warna produk menjadi sedikit lebih gelap. Berdasarkan penilaian dampak penggunaan fortifikan Fe-sulfat, Fe-fumarat dan Fe-EDTA terhadap produk roti tawar, roti manis, pao, cookies, mi, dan pasta, maka Fe-fumarat lebih direkomendasikan dijadikan sebagai fortifikan zat besi karena memberikan dampak terhadap perubahan sensori yang kecil dibandingkan dengan fortifikan sebelumnya (Feelemental).

\section{UCAPAN TERIMA KASIH}

Ucapan terima kasih kepada Direktorat Gizi Masyarakat, Kementrian Kesehatan, Indonesia; Yayasan Koalisi Fortifikasi Indonesia (KFI); Asosiasi Produsen Tepung Terigu Indonesia (Aptindo) : PT Bungasari Flour Mills; PT Pundi Kencana; PT Bogasari Flour Mills; PT Sriboga Flour Mill; PT Eastern Pearl Flour Mills; PT Nutrindo Bogarasa (Mayora Group); PT Cerestar Flour Mills; Micronutrient Initiative (MI) Indonesia; Stern Ingredients Asia-Pacific Pte. Ltd. Singapore.

\section{DAFTAR PUSTAKA}

Allen L, deBenoist B, Dary O, Hurrel R. 2006. Guidelines on Food Fortification with Micronutrients. World Health Organization, Food and Agricultural Organization of the United Nations. Geneva, Switerland.

Aulia SS, Rustanti N, Fitran DN. 2017. Fortifikasi nafeedta pada cookies ubi jalar kuning sebagai 
produk alternatif untuk menanggulangi anemia defisiensi besi. J Gizi Pangan 12(3): 161-168. DOI: 10.25182/jgp.2017.12.3.161-168.

[BSN] Bandan Standarisasi Nasional Indonesia. 2009. SNI 357: Tepung Terigu sebagai Bahan Makanan: BSN, Jakarta.

Chaudari R, Fanion M. 2008. Technical Aspects of Micronutrient Addition to Foods. Ottaway PB, editor. Food Fortification and Supplementation: Technological, Safety and Regulatory Aspects, CRC Press, Woodhead Publishing Limited, Cambridge, England.

Hurrell R, Ranum P, de Pee S, Biebinger R, Hulthen L, Johnson Q, Lynch S. 2010. Revised recommendations for iron fortification of wheat flour and an evaluation of the expected impact of current national wheat flour fortification programs. Food Nutr Bull 31(1): 7-21. DOI: 10.1177/15648265100311S 102.

Husna NN. 2011. Efektifitas FeSO4 dan FeSO4+ NaEDTA sebagai Fortifikan zat besi pada Susu Kedele dan Tempe. [Skripsi]. Jakarta: Fakultas
Matematika dan Ilmu Pengetahuan Alam (MIPA), Universitas Indonesia.

Lotfi M, Mannar MGV, Merx RJHM, de Heuvel PN. 1996. Micronutrient Fortification of Food: Current Practice, Research, and Opportunities. International Development (IDRC), International Agriculture Centre, Ontario, Canada.

Mangalik G, Martianto D, Sukandar D. 2016. Estimasi potensi kerugian ekonomi dan biaya penanggulangan akibat anemia di indonesia. J Gizi Pangan 11(3): 237246. DOI: 10.25182/jgp.2016.11.3.\%25p.

Meilgaard MC, Civille GV, Carr BT. 2016. Sensory Evaluation Technique. CRC Press Taylor \& Francis Group, Boca Raton, USA.

Uauy R, Hertrampf E, Reddy M. 2002. Iron fortification of food: overcoming, technical, practical barrier. The J Nutr. 132(4): 849-852. DOI: 10.1093/jn/132.4. 849 s.

JMP-05-18-16-Naskah diterima untuk ditelaah pada 18 Mei 2018. Revisi makalah disetujui untuk dipublikasi pada 1 April 2019. Versi Online: http://journal.ipb.ac.id/index.php/jmpi 